\title{
Folkebibliotekerne
}

\section{i Sønderjylland før 1920}

\author{
Biblioteker som instrumenter i det \\ nationale arbejdes tjeneste
}

Af Lars N. Henningsen

Slesvig, eller Sønderjylland, som er det gamle danske navn på landsdelen mellem Kongeåen og Ejderen, har en plads i både dansk og tysk bibliotekshistorie. En vigtig plads. Gennem århundreder, og i særlig grad i de hundrede år fra omkring 1840 og frem mod vore dage, har det nationale spørgsmål sat dagsordenen i dette grænseland mellem dansk og tysk. Uendelige kræfter er anvendt på at styrke og fremme henholdsvis dansk sprog og kultur og tysk sprog og kultur. For begge parter var styrkelsen af egen position længe ikke det eneste mål. At trænge den anden part, modparten, tilbage blev let den vigtigste ambition.

Konfrontationen fandt udtryk på mange måder. I 1800-årene undgik man ikke krudt og kugler. Men det var dog heldigvis undtagelsen. Mere permanente var kulturfrontens fredelige bestræbelser. I første række stod skolerne, dernæst kom bibliotekerne. Det betyder, at bibliotekshistorien mellem Kongeåen og Ejderen har fầet sit eget særpræg, præget af den nationale kappestrids udfordringer. Det gav bibliotekshistorien syd for Kongeåen en særlig betydning.

Lars N. Henningsen, arkivar, dr.phil.; Dansk Centralbibliotek for Sydslesvig, Flensborg. Artiklen gengiver $i$ omarbejdet form det foredrag, som blev holdt $i$ Dansk Bibliotekshistorisk Selskab $i$ anledning af overrakkelsen af E.C. Werlauff Prisen til Lars N. Henningsen den 26. oktober 1994. 
Jeg vil fremhæve to forhold. For det første selve ordet folkebibliotek. I dag er ordet den enerådende betegnelse for vore almenbiblioteker til forskel fra videnskabs- eller fagbibliotekerne. I tiden forud, sidst $i$ 1800-årene, benyttede man om datidens bogsamlinger til brug for menigmand mest betegnelser som sognebogsamling, sognebibliotek eller folkebogsamling. ${ }^{1}$ Først omkring 1920 sejrede ordet folkebibliotek i vore dages betydning. Det skete, da den forste moderne bibliotekslovgivning hævede almenbibliotekerne op på et nyt og højere niveau. Da valgte man ordet folkebibliotek som barnets navn. Ordet udtrykker gennem de to forskellige led nyskabelsens særpræg. Det første led folke- betegner det almene, folkelige sigte. I sidste led -bibliotek markeres det nye kvalitetskrav. Ordet bibliotek havde hidtil været forbeholdt de mere videnskabeligt orienterede specialbogsamlinger, som næsten alle havde hjemme i byerne. $\mathrm{Nu}$ blev ordet bibliotek overført til de nye almenbogsamlinger med det brede kvalitetspræg.

Ordet folkebibliotek slog således først igennem i dette århundrede. Men det havde dog en forhistorie også i 1800-årene. Efter alt at dømme blev det første gang bredt benyttet som led i bogarbejdet $\mathrm{i}$ Slesvig i 1850'erne, i tiden mellem de slesvigske krige. Folkebiblioteket - eller rettere ordet folkebibliotek - har altså rod i Slesvig. Og disse slesvigske "folkebiblioteker " var et af de markante midler i det ejderdanske arbejde forud for 1864 .

For det andet: Sønderjyllands bibliotekshistorie er udtryk for et paradoks. Vel indtager Sønderjylland en markant plads i dansk bibliotekshistorie. Men samtidig er den sønderjyske biblioteksudvikling væsensforskellig fra den danske. I kongeriget Danmark kan bibliotekernes udvikling fra 1700 -årene og frem mod i dag forklares blot med henvisning til ønsket om bedre og bredere oplysning af befolkningen. Rationalismens bestræbelse for at skabe almuebogsamlinger, Landhusholdningsselskabets initiativer og alle de andre forsøg frem til Selskabet for Trykkefrihedens rette Brug i årene 1835-48 på at udbrede god læsning og at grundlægge bogsamlinger er børn af oplysningstidens tanker. ${ }^{2}$ Også den senere udvikling - fra pioneren Andreas Schack Steenberg, Statens Bogsamlingskomité 1910 
og biblioteksloven af 1920 og fremefter - foregik helt i folkeoplysningens ånd. ${ }^{3}$ Den moderne demokratiske udvikling virkede $\mathrm{i}$ samme retning. Bibliotekerne skulle bidrage til at give befolkningen den oplysning, som var en forudsætning for aktiv deltagelse i det nye politiske liv. ${ }^{4}$

Syd for Kongeåen var det anderledes. Gennem århundrederne blev Kongeåen uddybet til et stadig dybere skel mellem Kongeriget og Sønderjylland/Slesvig, langt dybere end Skagerraks brede vand til Norge. I denne såkaldte "tyske provins" begyndte bibliotekshistorien i oplysningens ånd ligesom i det øvrige Danmark, og indtil 1830'erne fulgte den i Slesvig de samme spor som i Kongeriget. Bogen skulle tjene oplysningens sag. Men da den nationalt-sproglige kamp kom på dagsordenen fra sidst i 1830 'erne, fik bogen en ny opgave. Den blev også led i en anden sags tjeneste. Eller som en hjemmetysk bibliotekshistoriker i Nordslesvig har udtrykt det: "I grænseområder har biblioteker siden deres opståen en særlig opgave.$^{5}$

Det betød, at bibliotekerne fra 1830'erne og fremefter blev præget af det nationale arbejdes krav. Bibliotekerne udvikledes som led i den nationale kappestrid. Denne kappestrid er fortsat lige til den nyeste tid, og den har fieks. medført, at biblioteksstandarden blev højere i Sydslesvig end i egnene syd derfor - hvor der jo ikke var en konkurrent at måle sig med. Denne historisk betingede forskel i kvalitetsniveau mellem Sydslesvig og Holsten ses den dag i dag.

Den nationale dimension i biblioteksarbejdet markerer forskellen mellem Sønderjylland og Kongeriget, og den kom til at præge udviklingen lige fra 1830 'erne og langt frem i vort århundrede. Da udgiveren af Dannevirke, Peter Kr. Koch, som næsten den allerførste den 27. november 1838 foreslog oprettelse af permanente små-bogsamlinger, begrundede han det med, at "disse vilde udgjøre et godt Dannevirke ", altså et værn for dansk sprog og nationalitet. ${ }^{6} \mathrm{Da}$ Foreningen til det danske Sprogs Bevarelse i Nordslesvig (Sprogforeningen) opbyggede sine mange små bogsamlinger $\mathrm{i}$ årene fra 1880 , skete det som led i arbejdet for at styrke det danske sprog over for den tiltagende fortyskning. ${ }^{7} \mathrm{Og}$ da den senere landsbibliotekar $\mathrm{i}$ Aabenraa, Jacob Petersen, talte på Danmarks Biblioteksforenings 


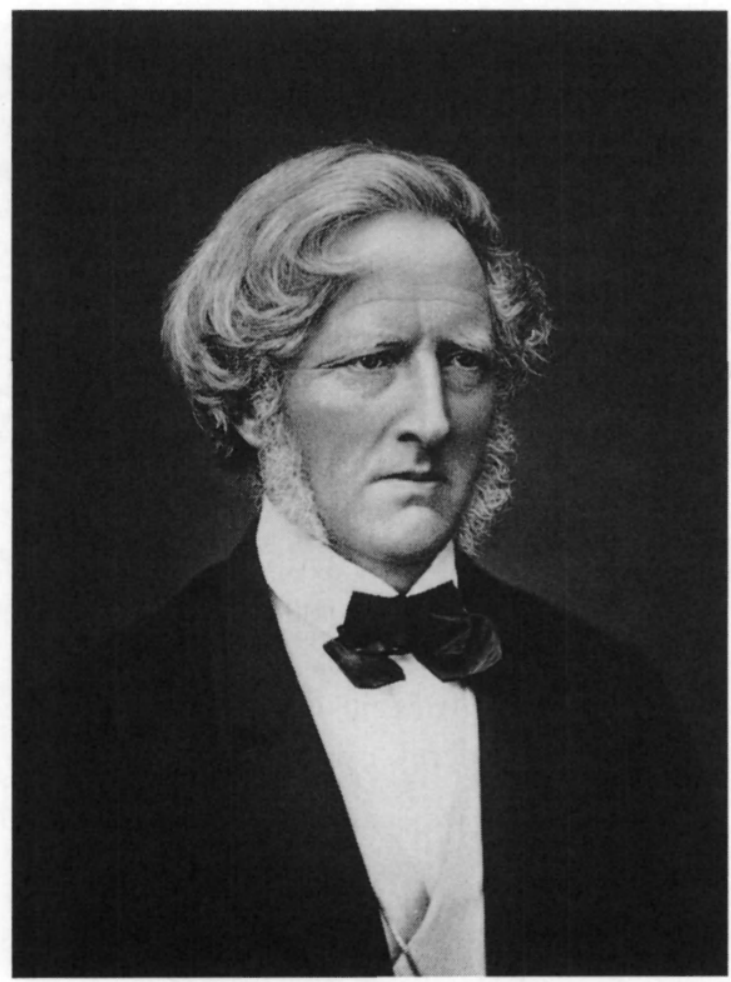

Peter Chr. Koch (1807-80) i

Haderslev blev ikke blot kendt som grundlagger og redaktør af bladet "Dannevirke" $i$ 1838. Han gav samtidig stodet til oprettelse af de danske sognebiblioteker. Aret efter stiftede hans svoger Nis Hanssen i København Foreningen til dansk Lasnings Fremme $i$ Slesvig, og sorgede på den måde for at omsatte Kochs idé i praksis. Dansk Centralbibliotek for Sydslesvig.

første årsmøde i Vejen i juni 1920, udtalte han, at de kommende biblioteker i det nu danske Nordslesvig ikke blot skulle være kulturcentre, men også kampcentre. ${ }^{8}$ På tilsvarende måde var den tyske stats særbevillinger til lærer-, skole- og folkebiblioteker fra 1880 'erne begrænset til de dansksprogede egne i Nordslesvig. Man støttede tyske folkebiblioteker, i bevidst modsætning til de danske bogsamlinger.

I Sønderjylland eller Slesvig skal bibliotekshistorien altså ses i lyset af den sprogligt-nationale udvikling. I det følgende vil vi lægge nogle snit gennem den danske og tyske bibliotekshistorie i Sønderjylland. Vi vil betragte bibliotekerne ud fra det motiv, som var det vigtigste ved deres grundlæggelse: De skulle være midler i det nationale arbejdes tjeneste. 


\section{Oplysnings- og skolebiblioteker}

De folkelige bibliotekers stamtræ har flere grene. Ældst er de små almenbiblioteker i oplysningstiden og de skole- og lærerbiblioteker, som opstod på baggrund af almenskoleloven af 1814. De havde alle til formål at fremme den almene oplysning og den kristelige, borgerlige og moralske dannelse.

De første forsøg møder vi i slutningen af 1700 -årene som udtryk for oplysningstidens idealer. I Haderslev fandtes et "læseselskab « i $1781,{ }^{9}$ og et årti senere omtales lignende selskaber i Husum, Slesvig, Frederiksstad, Tønning, Flensborg og Tønder. På landet omtales bondelæseselskaber i Ejdersted fra 1795, i Angel fra o. $1786 .{ }^{10}$

I centrum for de mange bestrabelser stod skolerne, og de var derfor også udgangspunkt for mange af de første almene bogsamlinger. Ikke mindst på Haderslev-egnen var aktive oplysningspræster optaget af sagen. Pastor Jørgen Mechlenburg (1741-1808) i Højrup sogn oprettede 1786 et skolebibliotek i byen Arnum. To år senere udgav han bogen Uforgribelige Tanker til noermere Eftertanke om Midler til Land-Almuens bedre Oplysning, isar formedelst Skolevasenets Forbedring. Her kunne man læse om ideer til indretning af skolebiblioteker og valg af gode bøger. I samme and virkede Haderslevtidsskriftet Haderslevsk Maanedsskrivt 1793-94. ${ }^{11}$ På Als blev der fra 1797 oprettet sognebogsamlinger eller skolebiblioteker i Nordborg, Svenstrup, Ulkebøl og Tandslet sogne, og der kom noget lignende i Øster Løgum og Vedsted. ${ }^{12}$

Oplysningsvennerne støttede energisk dette arbejde for at udbrede læsning og bogsamlinger til "almuen«. Men der lød også mange kritiske røster. De nye skole- og bibliotekstanker blev nogłe steder opfattet som forsøg på at gribe ind $\mathrm{i}$ bøndernes lokale selvbestemmelse, og de kunne let medføre nye økonomiske byrder. Derfor var der en del bønder, som kritiserede Mechlenburgs tanker. ${ }^{13}$

Mange præster var med i arbejdet, men også her var der skeptikere. I 1813 gav pastor Fr. M. Meyer i Havnbjerg udtryk for en ret almindelig skepsis, da han skrev følgende til brug for sin biskop: "Offentlige Bogsamlinger findes her i Sognet ikke. Bibelen, Lærebogen og Psalmebogen ere her instar omnium [gælder her lige så meget som alt andet], og når mine, nu i fjerde Kald stadfæstede 
Erfaringer, ikke aldeles bedrage mig, saa tabe Gudsfrygt og Retfærdighed ei derved, at Almuen ikke bliver opblæst ved en blandet Læsning, som den har saare sjælden Styrke nok til at fordøie «. ${ }^{14}$ Pastor Meyer var dog ikke talerør for den herskende opfattelse.

Året efter fik tankerne i oplysningstidens mange lokale skoleordninger almen gyldighed i Slesvig. Almenskoleloven af 24. august 1814 fastslog i $\$ 75$, at der skulle opbygges et skolebibliotek i hvert sogn. Biblioteket skulle stå i præstegården, og det skulle finansieres afiet årligt tilskud fra sognets kirkemidler. Der skulle købes bøger til almen brug for lærere og børn. ${ }^{15}$

Denne bestemmelse blev grundlaget for skolebibliotekernes opbygning i lange tider, også i den tyske tid efter $1864 .{ }^{16}$ Men lov er ét, virkelighed noget andet. Det viste sig hurtigt vanskeligt at få reglerne gennemført, og i en del sogne gik der år, før et skolebibliotek blev oprettet. Gang på gang blev det nødvendigt at skærpe kontrollen med reglernes overholdelse. Mere fasthed over sagen kom der først, da et nyt cirkulære i 1836 indskærpede præsternes pligt til at opkræve det årlige beløb fra kirkekassen til skolebiblioteket. Det blev foreskrevet, at der skulle føres årligt regnskab over skolebibliotekernes indtægter og udgifter. Ved hver visitats skulle regnskabet forelægges visitatorerne til revision sammen med en fortegnelse over de anskaffede bøger, "som samtidigt ville være at forevise; hvorhos det fremdeles skal være kirkevisitatorerne overladt at meddele præsterne de fornødne bemærkninger, når de ikke måtte finde det ved bøgernes anskaffelse trufne valg heldigt «. Der skulle føres fortegnelser over bøgerne, og præsterne skulle være ansvarlige for deres ordning, benyttelse og bevaring. ${ }^{17}$

Cirkulærets detaljerede regler satte spor. Fra dette tidspunkt blev der opbygget skolebiblioteker de fleste steder. De bevarede arkiver viser, hvordan arbejdet forløb i praksis. Provsterne efterså skolebibliotekernes bogfortegnelser ved de årlige visitatser og fik forelagt beretninger derom fra lærerne. ${ }^{18}$ Biskoppen (generalsuperintendenten) modtog ved sine visitatser redegørelser fra præster og lærere om kirkens og skolens forhold, og heri indgik der afsnit om skolebibliotekernes tilstand. ${ }^{19}$ 
På dette grundlag kan man følge bogsamlingernes gradvise opbygning. Efter alt at dømme blev de næsten udelukkende målrettet mod lærernes behov og blev ikke benyttet af eleverne. I 1850'erne blev reglerne strammet op. I Tønder provsti genindførtes 1851 pligten for de lokale kirkekasser til at yde det årlige tilskud ubeskåret til skolebiblioteket. ${ }^{20} \mathrm{I}$ de følgende år måtte lærerne aflevere fortegnelser over skolebibliotekerne ved de årlige provstevisitatser. ${ }^{21} \mathrm{I} \mathrm{Ha}-$ derslev provsti udbad provsten sig fra 1854 fortegnelser over bogbestanden og nyerhvervelserne. ${ }^{22}$ Disse skolebiblioteker bestod næsten udelukkende af litteratur til brug i religionsundervisningen (bibel- og testamenteudgaver, bibelhistorier, salmebøger og gejstlig litteratur), læsebøger og sproglære, regnebøger, geografi og historie. Bøger af underholdende og alment oplysende karakter, som kunne tænkes at fange elever eller sogneboere i øvrigt, var der næsten ingen af.

Efter 1864 gik tilsynet med skolebibliotekerne over til de nye tyske myndigheder. Det betød i første omgang ikke de store ændringer. Arbejdet fortsatte i det gamle spor, og igen viste det sig, at et skærpet tilsyn kunne være på sin plads. ${ }^{23}$ Mange steder var det årligt foreskrevne tilskud fra kirkekassen i de foregående år anvendt til indkøb af bøger til fattige børn, ikke til skolebiblioteket. Og hvor biblioteket levede, havde det som før nævnt mest karakter af lærerbibliotek, sammensat af teologisk og pædagogisk litteratur til gavn for læreren. Her var der ikke meget at hente for den unge eller ældre laser, som ønskede bøger af mere almen og underholdende karakter. "Folkebiblioteket " kan altså ikke føre sine aner tilbage til disse lærerbiblioteker!

Folkebiblioteket - et barn af Slesvigs "danisering"

I stedet må vi søge andetsteds, nemlig blandt de nye bogsamlinger, som skabtes fra 1830'erne som led i den danske vækkelse af Sønderjylland. Det er disse bogsamlinger, som fik betegnelsen folkebiblioteker.

Den første begyndelse foregik i oplysningstidens ånd. I Kongeriget grundlagdes 1835 Selskabet for Trykkefrihedens rette Brug. ${ }^{24}$ Selskabet uddelte bøger, fra 1836 også i Slesvig. Men den planløse 
spredning af bøger hjalp ikke meget, og den vakte ikke begejstring hos de mænd, som drømte om Sønderjyllands folkeligt-danske vækkelse. Redaktør Peter Chr. Koch på Dannevirke i Haderslev skrev i 1838 lidt spidst, at det ikke var nok blot at "køre hele læs bøger over på den slesvigske ager". Det ville give "lige så megen frugt som en skæppe sure æbler i værdi«. Nej, der skulle i stedet $» \mathrm{i}$ enhver egn oprettes små lånebiblioteker", altså permanente bogsamlinger. ${ }^{25}$

Dermed var Kochs initiativ udtryk for noget nyt. Sammen med professor Chr. Flor fra Kiel lagde Koch ud med bogsamlinger i Haderslev og Aabenraa. Man ønskede noget andet end de hidtil kendte almuebogsamlinger fra oplysningstiden, hvor vægten lå på den nyttige og praktisk orienterede litteratur. Flors program var den digteriske fornyelse af folkets gamle åndsskatte. For at skaffe gode bøger lod Flor en af sine venner i Trykkefrihedsselskabet, pastor J.V.Marckmann, indrykke en annonce i nogle københavnerblade. Her meddeltes, at nogle folkevenner $i$ en af provinserne havde oprettet biblioteker, og publikum blev bedt om at stille gode folkebøger til rådighed. Ikke oplysningstidens nyttige bøger, men bøger til almen dansk folke-dannelse var nu sagen.

Resultatet af Kochs initiativ blev i første omgang kun beskedent. Men den 11. april 1839 bragte en række sønderjyder i København for alvor sagen fremad. De stiftede Foreningen til dansk Lasnings Fremme $i$ Slesvig. Den fik i løbet af kun to år startet 60 bogsamlinger med i alt 14.000 bind i Sønderjylland. ${ }^{26}$

Disse bogsamlinger blev omtalt i præsternes og lærernes visitatsberetninger ved siden af omtalen af skolebibliotekerne, og ad denne vej kan vi danne os et indtryk af samlingernes karakter. Man møder lokale læseforeninger allerede fra $1839 .{ }^{27}$ Før Treårskrigen nåede

I tiden mellem de slesvigske krige blev der isar indkobt underholdende litteratur til de danske folkebiblioteker $i$ Sonderjylland. I Tonder oprettedes en "dansk skolebogsamling", som rummede alle de typiske boger, som blev indkabt til de danske bogsamlinger $i$ disse år. Samlingen der sidenhen indgik $i$ Tonder Seminariums bibliotek bestod af ca. 800 bind, iscer skonlitteratur, religion, historie, personalhistorie, rejseskildringer, topografi og'geografi. Ca 360 bind er bevaret $i$ dag. 


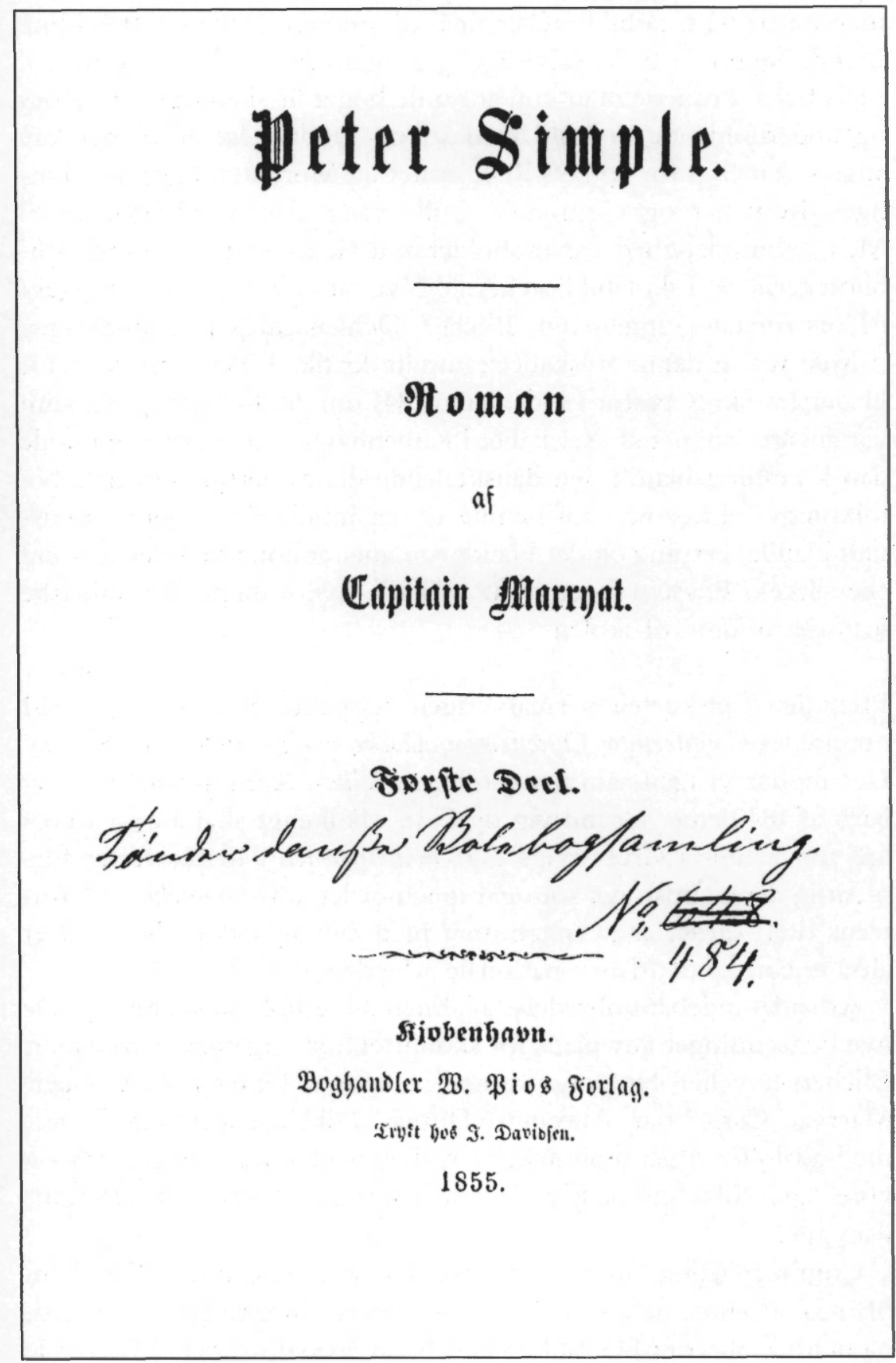


man op på 62 små biblioteker med tilsammen 20.000-25.000 bind. Blandt bøgerne var der selvfølgelig gengangere fra oplysningstiden. I Jels f.eks. ønskede man kun at samle bøger af "lærerigt og nyttigt og underholdende Indhold med streng Undtagelse af alt der kan ansees skadeligt for Folkets Religiøsitet og Moralitet, ligesom navnligen Romaner og Comødier skulle være aldeles udelukkede ". ${ }^{28}$ Men i almindelighed var indholdet anderledes end i oplysningsbibliotekerne og i skolebibliotekerne. Nyt var de mange "folkebøger " i Flors forstand, Ingemann, Blicher, Oehlenschläger, Grundtvig. ${ }^{29}$

Men netop denne nyskabelse mødte kritik. I Tyrstrup nord for Haderslev skrev pastor Lindenhahn 1841 om det filialbibliotek, som var anlagt i sognet af "selskabet i København, der søger at udbrede dansk læsning blandt den dansktalende del af hertugdømmets befolkning ": "Efter min formening er det imidlertid uafgjort, hvorvidt blandet læsning og deriblandt romaner er bondestanden gavnlig eller ikke«. Præsten foretrak at anskaffe nye testamenter, bibelske historier o. lign. til skolen. ${ }^{30}$

Efter den danske sejr i Treårskrigen begyndte man på ny. I 1851 oprettedes Comiteen for Oprettelse af danske Folkebibliotheker i Slesvig. Her møder vi igen sammensætningen folke-. Kombinationen er et barn af 1840 'erne, Grundtvig og Flor. "Folkeligt skal alt nu være" lød første linje i Grundtvigs digt Folkeligheden i 1848. Det er formentlig denne tidstone, som går igen i ordet folkebiblioteker i Comiteens titel. Ordet er jævngammelt med folkehøjskolen. Begrebet er altså et barn af det dansk-nationale arbejde i Slesvig.

Arbejdet indebar udbredelse af almen underholdningslæsning. De nye bogsamlinger gav plads for skønlitteratur: Ingemanns romaner, Blichers noveller, Holbergs komedier, og man kunne finde Cooper, Marryat, Carit Etlar, Alexandre Dumas, folkekalendere osv. ${ }^{31}$ Dermed adskiller disse biblioteker sig dog også fra en senere tids og vore dages folkebiblioteker. De satte ganske den oplysende litteratur i skygge.

Comiteen havde langt mere succes end Foreningen fra 1839. Frem til 1864 udsendte den 66.457 bøger og småskrifter til Sønderjylland, og den fik oprettet 143 biblioteker, heraf 56 syd for den nuværende 
landegrænse. ${ }^{32}$ De gode resultater skyldtes ikke mindst, at de ofte nyansatte danske præster og enkelte lærere tog sig af sagen.

Målet var et andet end for oplysningstidens almuebogsamlinger, for slet ikke at tale om skolebibliotekerne. Målet var nu "det kære modersmaals oprejsning og renselse", således som præsten i Fjolde sogn, Carl Mule, udtrykte det. ${ }^{33}$ Disse folkebiblioteker var et "Middel til at styrke den danske Nationalitet og befæste Kjærligheden til vort Fædreland, dets Sprog og Litteratur«. De skulle hjælpe til at "knytte denne dyrekjøbte danske Landsdeel saa nær til Kongeriget som muligt $«{ }^{34}$

\section{Tyske folkebiblioteker og elevbiblioteker}

Vi har nu døbt det danske folkebibliotek som et barn af 1840'ernes og 1850'ernes nationale vækkelse. Det kræver, at linjen trækkes op gennem århundredet. Hvordan blev folkebibliotekets skæbne i Sønderjylland senere i århundredet?

Efter 1864 gik de danske folkebiblioteker i opløsning. Den nye preussiske forvaltning tog fat på at germanisere Slesvigs dansktalende del. Skolerne og bibliotekerne var vigtige midler i denne bestræbelse. Fra 1878 gennemførtes en kraftig kontrol med skolebibliotekerne. Reglerne fra 1814 og 1836 blev indskærpet, og de nye embedsmænd, kredsskoleinspektørerne, fik til opgave at visitere skolebibliotekerne. ${ }^{35}$ De var ikke alle steder i god stand. Der blev givet anvisninger om, hvilke bøger der skulle indkøbes. Det skulle være tyske bøger, som kunne vække sansen for [det tyske] fædrelandets historie, litteratur og kultur, og som også kunne tjene lærernes videre dannelse samt skolernes pædagogiske opgave. Disse generelle retningslinjer blev suppleret af lister over anbefalelsesværdige bøger. Som hidtil skulle der indsendes årlige lister over bibliotekernes indhold. Der blev også oprettet særlige kreds-lærerbiblioteker, især i Nordslesvig, et for hvert amt. ${ }^{36}$

Derefter satte den tyske forvaltning ind på nye områder. Det gjaldt om at give tyskundervisningen den rette boglige støtte. Derfor kom nye biblioteker fra slutningen af 1870'erne på programmet. Det var de såkaldte tyske elevbiblioteker og især tyske folkebiblioteker. Programmet var en del af datidens almene tyske arbejde for "Volks- 
bildung ", men her i Nordslesvig fik det sit særlige præg som led i germaniseringen. Arbejdet fandt kraftig støtte $\mathrm{i}$ den halvofficielle sammenslutning Schleswig-Holsteinischer Verein zur Verbreitung von Volksbildung i Kiel. Målet var en "staatserhaltende" Volksbildung, hvor ikke kun det danske og andre mindretal, men også socialdemokraterne var de slemme fjender. ${ }^{37}$

De nye biblioteker skulle delvis bygge på frivillige bidrag. Af statsmidler skulle der ydes tilskud i egne med dansk folkesprog, efter modellen: et lokalt tilskud til biblioteket udløser et statsligt tilskud af dobbelt størrelse. En sådan model kendes jo også i senere bibliotekslovgivning. Lærerne blev kraftigt tilskyndet til at påtage sig bestyrelsen af disse "folkebiblioteker «. De skulle indeholde bøger af underholdende art, som kunne vække læselysten og påvirke ånd og følelse. Især burde der være historiske værker, som kunne skabe fædrelandskærlighed. ${ }^{38}$

Som venteligt stødte initiativerne på modstand i de dansktalende egne. En del steder var der ikke megen lyst til at yde bidrag, medmindre man også kunne indkøbe danske bøger! Mange præster frarådede oprettelse af nye tyske folkebiblioteker. ${ }^{39}$ De tyske bøger ville foreløbig ikke finde mange læsere, "da kun fầ blandt de fầ tysksindede beboere kan læse tysk og andre overhovedet ikke læser ", som præsten i Felsted skrev. ${ }^{40}$

Målet for de nye tyske folkebiblioteker var klart nationalt. En beretning fra den positivt indstillede pastor E.A.F. Jessen i Ravsted 1882 er ganske typisk. Han indberettede, at sognet i årene 1854-64 af: den danske regering havde făet et stort antal dansk-patriotiske bøger. Nogle fandtes endnu, men de fleste var bortkommet, og et egentligt folkebibliotek eksisterede ikke. "Hvis regeringen ville være mig behjælpelig ved oprettelsen af et sådant, " fortsatte han, "så ville det være mig en stor glæde at gøre alt hvad jeg kan for en så almennyttig foranstaltning, som faktisk ønskes af mange, og som også kunne være meget hensigtsmæssig for at styrke tyskheden " ${ }^{41}$ Det må tilføjes, at Ravsted var et sogn med et anseligt antal tysksindede. 
Trods de lokale betænkeligheder blev værket sat i gang. Fra omkring 1877 oprettedes en hel række tyske folkebiblioteker. I Tønder kreds steg antallet fra 8 i 1883 til 18 i 1888 og 22 i $1899 .{ }^{42}$ I Aabenraa kreds oprettedes 1879-91 16 tyske folkebiblioteker med i alt knap 1700 bind. ${ }^{43}$ Samlingerne var kun små, som regel mellem 50 og 300 bind. De blev bestyret af degne, lærere og præster, som opkrævede "læsepenge" fra folk, som kunne betale. Men benyttelsen var kun såre beskeden. Samtidig oprettede Deutscher Verein für das Nördliche Schleswig (Den tyske Forening for det nordlige Slesvig) biblioteker. I 1901 stod den bag 32 biblioteker med tilsammen 6000 bind. ${ }^{44}$ Utraditionelle veje blev også taget $\mathrm{i}$ brug for at bringe den tyske bog ud til alle. Man stationerede bogkasser på småbanestationerne til brug for de rejsende, og i de enkelte amter blev der oprettet vandrebiblioteker. $^{45}$

Bogudvalget i de tyske folkebiblioteker var som nævnt foreskrevet ovenfra. Der skulle være tysk skønlitteratur af underholdende karakter, som kunne virke dannende på ånd og følelse, samt bøger af historisk indhold egnet til at vække fædrelandskærlighed. Rent belærende bøger blev ikke anbefalet, da det gjaldt om at vække læselysten. ${ }^{46}$ Boglisterne svarer hertil. Der var tysk skønlitteratur de store navne som Schiller, Goethe, mange mindre digtere - og en mængde tysk krigs- og kejserhistorie.

Men for alle disse tyske folkebiblioteker gjaldt, at læserne svigtede. De kunne ikke konkurrere med Sprogforeningens bogsamlinger, som opstod i stort tal efter foreningens oprettelse i 1880. Dette danske modstød var et godt argument for at søge tilskud til de tyske biblioteker, så man kunne "styrke benyttelsen og derved modvirke det danske bibliotek " ${ }^{47}$ I Aabenraa amt var der således 188913 tyske folkebiblioteker med kun 1498 bd., og 17 sprogforeningsbiblioteker med 3967 bd. ${ }^{48}$ I 1892 var tallene vokset til henholdsvis 16 tyske biblioteker med 2186 bind og 17 danske med 40005000 bind. ${ }^{49}$ Der er ikke tvivl om, at trængslen var størst i de bondestuer, som gav husly til Sprogforeningens bøger. 
Nyt tysk fremstød

Hen mod slutningen af 1890 'erne stod det klart for myndighederne, at "folkebiblioteksforsøget" var slået fejl. Sprogforeningens succesrige fordeling af dansk lekture og dens påvirkning af befolkningen $\mathrm{i}$ "tyskfjendtlig retning" krævede en modvægt. I 1896 gik de højeste myndigheder - ministeriet i Berlin og overpræsidenten og regeringspræsidenten i Slesvig - til angreb. De tyske folkebiblioteker skulle være mere effektive, så de bedre kunne "fremme tyskheden $\mathrm{i}$ Nordslesvig ". Standarden skulle forbedres, og der skulle tilføres flere ressourcer, så bogbestanden kunne tiltrække læserne. Vejen frem måtte gå gennem øget central styring. Derfor blev kredsskoleinspektørernes tilsyn nu udstrakt til at omfatte folkebibliotekerne. Hidtil havde de kun ført tilsyn med skole- og elevbibliotekerne. Der blev bevilget øgede tilskud, som udelukkende skulle anvendes i egne med dansk folkesprog. Udveksling af bøger mellem de enkelte biblioteker blev foreskrevet for at forny tilbudet til læserne, og det blev anbefalet at oprette "folkelæseforeninger « ${ }^{50}$

Reaktionen i Nordslesvig var blandet. I Tønder kreds protesterede præsterne som bestyrere af folkebibliotekerne direkte mod den nye kontrol. Kredsskoleinspektør August Friedrich Emil Krage i Tønder gav i 1897 en meget nøgtern beskrivelse af de tyske folkebibliotekers situation. Den viser vanskelighederne og perspektiverne og fortjener at gengives:

"De fleste, især blandt de ældre, er for ukendte med tysk til at kunne læse de tyske bøger. De mangler også den tyske skolegang, som er en nødvendig forudsætning for at kunne forstå indholdet $\mathrm{i}$ folkebibliotekerne. Det stof, som behandles i folkebibliotekerne, ligger dem for fjernt og er derfor for svært for dem. For mange unge er de ældres indflydelse hindringen for at læse tyske bøger. En vis

Bibliotekerne var et vigtigt middel $i$ den nationale kamps tjeneste. Fra 1880 oprettede Sprogforeningen danske bogsamlinger. På tysk side blev der investeret $i$ tyske elevbiblioteker og isar tyske folkebiblioteker. I arkiverne er der bevaret et stort kildemateriale om disse biblioteker - det venter blot på at blive udforsket. Her ses et udsnit af listen over de tyske folkebiblioteker i Aabenraa amt fra 1890. Landsarkivet i Aabenraa. 
Lars N. Henningsen - Folkebibliotekerne i Sønderjylland for 1920

67

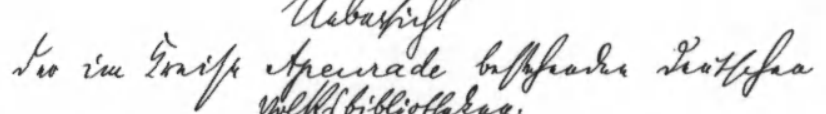

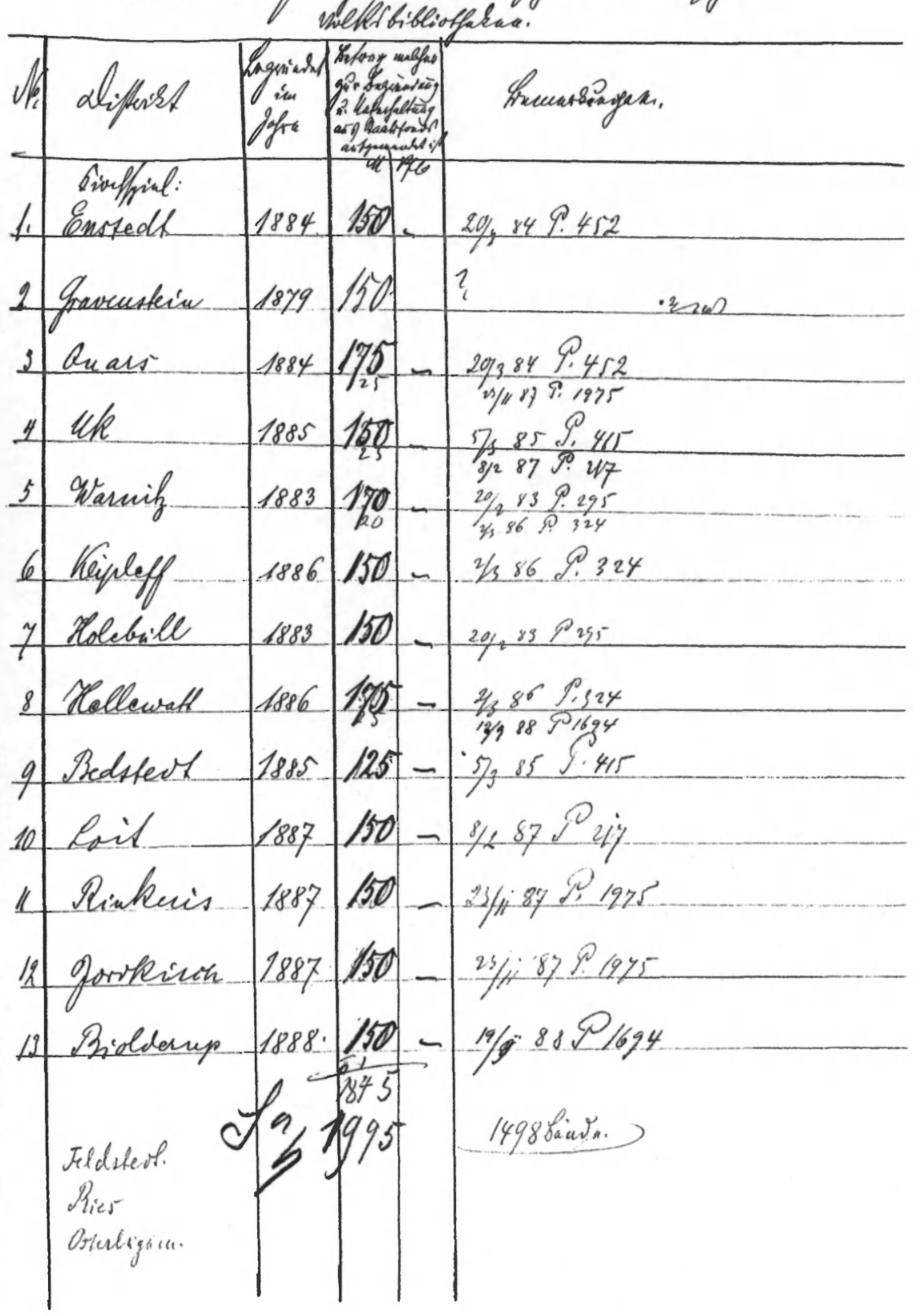


modvilje mod det tyske er heller ikke overvundet en del steder. Dertil kommer, at de danske folkebiblioteker, som findes i næsten alle sogne, $i$ indhold og sprog svarer bedre til folkedannelsen, som endnu hviler på dansk grundlag, end vore tyske biblioteker. Derfor foretrækkes de danske biblioteker fremfor vore. Desuden læses elevbibliotekerne af mange voksne med større iver, fordi de $\mathrm{i}$ form og indhold er lettere - og det er et meget glædeligt tegn. For det tyske folkebibliotek er tiden først inde, når skolen har udbredt den tyske dannelse mere alment, og når forståelsen for folkebibliotekerne er blevet forberedt gennem elevbibliotekerne."

Et vist håb så kredsskoleinspektøren dog $\mathrm{i}$ at lærerne lovede at virke for nygrundlæggelse og ville arbejde for at lede flittige læsere blandt eleverne over i folkebibliotekerne, når de havde forladt skolen. ${ }^{51}$

Krages redegørelse giver et realistisk billede af stillingen. De tyske folkebiblioteker mødte kun ligegyldighed hos de fleste, hvis ikke modstand, mens de tilsvarende danske folkebiblioteker - dvs. Sprogforenigens bogsamlinger - mødte megen interesse. Derimod synes de tyske elevbiblioteker at have haft nogen succes. Her så de tyske myndigheder et håb for fremtiden. Børnene kunne man lettere fă til at tage en bog med hjem. Men de gode lånertal for disse biblioteker skal nok tages med nogen skepsis - som al biblioteksstatistik til alle tider! I Sprogforeningen fremhævede man, at de tyske skolebibliotekers bøger blev påtvunget børnene til læsning hjemme, og mange lærere virkede desuden ved trusler og formaninger med til, at deres elever ikke lånte bøger fra Sprogforeningens bogsamling. ${ }^{52}$

Denne tyske bibliotekshistorie er hidtil ret ukendt. Der blev i tiden frem mod 1. verdenskrig ofret mange kræfter og overvejelser på at tilfredsstille befolkningens læsebehov. Men der lå en bestemt hensigt i arbejdet. I 1899 udsendte regeringspræsidenten i Slesvig følgende skrivelse: „I betragtning af det stærke behov for læsning, som råder hos den herværende befolkning, er det af største vigtighed at bevirke, at dette behov ikke tilfredsstilles på en måde, som er i modstrid med vore nationale og sociale interesser. Det middel, som 
bedst kan føre til målet, er skabelsen af folkebiblioteker fra myndighedernes side ". ${ }^{53}$

Bibliotekshistorien blev med andre ord styret af overordnede politiske målsætninger, ikke i første række af hensyn til en værdifri styrkelse af den almene oplysning. Det gjaldt i det små og i det store. I 1902 ønskedes f.eks. en udvidelse af det lille folkebibliotek i Emmerlev nord for Tønder. Det var grundlagt 1899 og omfattede kun 60 bind. Udvidelsen blev begrundet således: "Emmerlev er for største delen dansk. En udvidelse af biblioteket er derfor ønskelig af politiske grunde«. Også i Hostrup-Solderup-Jejsing burde biblioteket udvides "for atter at øge benyttelsen og derved modvirke en videre udbredelse af det danske bibliotek i nabolandsbyen Rørkær «. ${ }^{54}$

I årene efter århundredskiftet prøvede man i stigende grad at gå nye veje for at nå målet. Der blev som nævnt oprettet læsekredse og kredsvandrebiblioteker, og elev-, skole- og folkebibliotekerne modtog fortsat støtte. Det var sikkert ikke uden virkning. Men det endelige mål nåede man ikke. Genforeningen i 1920 satte punktum, og den er i sig selv bevis på, at bibliotekerne ikke nåede målet.

I deres kerne var alle de slesvigske "folkebiblioteker « i slægt med hinanden. De "deutsche Volksbibliotheken " var i slægt med de danske "folkebiblioteker « fra 1840-50'erne. Og Sprogforeningens bogsamlinger hørte til samme familie. De var alle midler i den nationale og sproglige kamps tjeneste.

\section{Udblik}

Vi har nu stiftet bekendtskab med et bredt udsnit af bibliotekerne $\mathrm{i}$ Sønderjylland i tiden frem til omkring 1920. Det har krævet, at vi har overskredet grænserne for den rent danske historie. Men sådan er betingelserne, når man vil arbejde med Sønderjyllands historie. I dag er Sønderjylland, eller rettere Nordslesvig, en del af Danmark. Indtil 1920 lå Kongeåen som det dybe skel. På næsten alle områder var der forskel på forholdene nord og syd for Kongeåen. Inddragelsen af Sønderjylland i rigsdanske fremstillinger kræver derfor ofte en separatfremstilling. Det viger mange tilbage for, og derfor udelades Sønderjylland ofte i rigsdanske fremstillinger. 
Ikke mindst inden for bibliotekshistorien er dette imidlertid uheldigt. Indtil 1864 var vekselvirkningerne mellem Kongeriget og Sønderjylland mange. Oplysningstiden fik begge steder ens udslag i bogverdenen, og opbygningen af de danske biblioteker i Sønderjylland fra sidst i 1830 'erne blev styret nordfra. Men det betød samtidig, at Sønderjyllands bibliotekshistorie fra dette tidspunkt og næsten til i dag fik en anden karakter end Kongerigets. I Sønderjylland blev ordet folkebibliotek holdt over dåben i 1840-50'erne, og i Flensborg blev der investeret $i$ et stort offentligt almenbibliotek allerede o. 1860. Netop den nationale og sproglige kamp blev drivkraften for bibliotekshistorien - anderledes end i Danmark.

Efter 1864 kom dertil impulserne fra prøjsisk bibliotekspraksis. Dette aspekt er hidtil relativt ukendt i Danmark, og det kan kun forstås på baggrund af udviklingen i vort naboland mod syd. Et ganske stort kildemateriale er bevaret om denne nye udvikling efter 1864. Det kunne være interessant at sætte bibliotekshistorien i Sønderjylland i dens fulde bredde, ikke kun de danske bogsamlinger, i relief overfor den samtidige udvikling i Danmark. Derved ville man kunne fastslå forskelle eller ligheder, parallelle eller modgående bevægelser, gensidige påvirkninger eller isolation. Den rigsdanske bibliotekshistorie ville sikkert vinde ved at indlade sig med det grænseoverskridende. Iagttagelsen af det uvante ville skærpe begrebsapparatet over for det nære.

Lad dette være en opfordring til fremtidige undersøgelser. 
NOTER OG HENVISNINGER

\section{Forkortelser}

LA Aab Landsarkivet for Sønderjylland, Aabenraa

LASH Landesarchiv Schleswig-Holstein, Slesvig

Chron Samml Chronologische Sammlung der ... Verordnungen ... für die Herzogthümer Schleswig und Holstein

SJy Årb Sønderjyske Årbøger

1. Se f.eks. terminologien i Marton de Hartyani: Sognebiblioteksundersøgelsen 1885. I: Bibliotekshistorie 1, København 1985, s. 70-72. - Sidst i 1800-årene synes ordet bibliotek hyppigst anvendt om de videnskabeligt orienterede bogsamlinger, således skolebiblioteker og stiftsbiblioteker, ordet bogsamling (eller ofte folkebogsamling) om de folkelige bogsamlinger. Blandingsordet folkebibliotek er altså udtryk for en tilnærmelse mellem bogsamlinger af forskellig oprindelse, eller med andre ord for det øgede niveau, som almenbibliotekerne oplevede fra sidst i 1800-årene og især efter 1920, da det moderne folkebibliotek blev virkelighed.

2. Helge Nielsen: Folkebibliotekernes forgængere. Oplysning, almue-og borgerbiblioteker fra 1770erne til 1834, København 1960. - Sigurd Nielsen: Selskabet for Trykkefrihedens rette Brug. I: Historiske Meddelelser om København, 4. rk. IV, 1954-57, s. 225-364.

3. Nordisk leksikon for bogvæsen, bd. 1, 1951, s. 307.

4. Jørgen Svane-Mikkelsen: En samfundsnyttig gerning. Træk af Koldings bibliotekshistorie. Kolding Folkebibliotek 1993, s. 9.

5. Peter J. Sönnichsen: Mehr als Bücher. Die Geschichte der deutschen Büchereien in Nordschleswig. Verband deutscher Büchereien in Nordschleswig, Flensborg/Aabenraa 1991, s. 22. Citatet er her oversat til dansk, hvilket også gælder efterfølgende citater fra tysksprogede kilder.

6. P. Lauridsen: Da Sønderjylland vaagnede, bd. 1, 1919, s. 210.

7. Anders Feilberg Jørgensen: Sprogforeningen gennem 100 år 1880-1980, Sønderborg 1980, s. 25-32.

8. H. Hvenegaard Lassen: De danske folkebibliotekers historie 1876-1940, København 1962 , s. $202 \mathrm{f}$.

9. Lars N. Henningsen: Johan Friedrich Camerer - en tysk-dansk patriot i 1700årene. I: SJy Årb 1993, s. 54.

10. Helge Nielsen, 1960, s. 187.

11. G. Japsen: Det dansksprogede skolevæsen i Sønderjylland indtil 1814, 1968, s. 282 og 284-87.

12. Helge Nielsen, 1960 , s. 230 og 256-58.

13. Lars N. Henningsen, 1993, s. 56.

14. G. Japsen, 1968, s. 387. 
15. Frdn. 24. aug. 1814, Chron Samml $1814 \$ 75$.

16. G.C. Kuntze: Das Volksschulwesen der Provinz Schleswig-Holstein, Schleswig 1887, bd. 1 s. 53 og bd. 2 s. $45-51$.

17. Cirkulære 29. marts 1836, Chron Samml.

18. Se f.eks. visitatser i Haderslev provsti: LA Aab, Haderslev Provstearkiv nr. 479. Visitatsprotokol 1840-60.

19. Se f.eks. vitatser i Haderslev provsti: LA Aab, Generalsuperintendenten, Abt. 18 nr. 41 (1841).

20. Chron Samml 1851, s. 110 nr. 60: 1851 2. aug. - I perioden 1816-51 var der årligt overført $1 \mathrm{rdl}$. årligt fra hvert sogn til opbygning af et provstibibliotek. Dette "skolelærerbibliotek for Tønder provsti« indgik 1861 i Tønder Seminariums bibliotek og findes endnu i dag bevaret $\mathrm{i}$ Tønder under betegnelsen "degnebiblioteket«. Det er en værdifuld samling af de gængse bøger til brug for lærere og degne i begyndelsen af 1800-årene. - Jf. S. Schoubye: Tønder Statsseminariums Bibliotek og dets Historie. I: Sønderjysk Månedsskrift 1947, s. 239. - 1788-1988 Tønder Statsseminarium. Et Jubilæumsskrift, Tønder 1988, s. 132.

21. Se f.eks. LA Aab, Tønder provsti, nr. 233.

22. LA Aab, Haderslev provsti, nr. 459.

23. Fornyet kontrol 1878: Rundschreiben 1878 11. december: Haderslebener Kreisblatt $1878 \mathrm{nr}$. 247. LA Aab, Haderslev provstearkiv nr. 466, fortegnelser over de enkelte skolebiblioteker.

24. Sigurd Nielsen, 1954-57, s $225 \mathrm{ff}$.

25. P. Lauridsen bd. 1, 1919, s. 210 og bd. 3, 1916, s. 10.

26. P. Lauridsen bd. 3, 1916, s. 7-20.

27. F.eks. Læseforeningen i Jels Sogn, oprettet 20. dec. 1839. Her var målet dog helt i oplysningstidens ånd: "Læeforeningens Formaal er Folkets Oplysning ved Anskaffelse af hensigtsmæssige og passende Bøger og Skrifter til almindelig Afbenyttelse«. LA Aab, Generalsuperintendentens arkiv, Abt 18 nr. 41 (pk. 3) Jels 1839.

28. Love for Jels Læseforening 1839; se note 27.

29. P. Lauridsen bd. 1, 1919, s. 209, 210, 213, 214; bd. 3, 1916, s. 7-20.

30. LA Aab, Generalsuperintendenten, Abt. 18 nr. 41 (pk. 3) 1841.

31. Se f.eks. liste over "Læseselskabsbiblioteket " oprettet 1854 i Tyrstrup bl.a. med gaver fra Comiteen for Oprettelse af danske Folkebibliotheker i Slesvig. LA Aab, Haderslev provstearkiv nr. 459.

32. Jakob Petersen: Danske Folkebiblioteker i Sønderjylland i tiden mellem krigene. I: Festskrift til H.P. Hanssen, 1932, s. 188ff. - Udsigt over den af Comiteen for Oprettelse af danske Folkebibliotheker i Slesvig udviklede Virksomhed. I: Slesvigske Provindsialefterretninger, bd. 2, 1862, s. 393-411.

33. Lars N. Henningsen: Dansk Biblioteksvirke i Sydslesvig, Flensborg 1991, s. 18. 
34. Udsigt over den af.Comiteen for Oprettelse af danske Folkebibliotheker i Slesvig udviklede Virksomhed. I: Slesvigske Provindsialefterretninger, bd. 2, 1862, s. 393 og 400.

35. G.C. Kuntze, 1887 , bd. 1 s. 53 og bd. 2 s. 45-51. - L.S. Ravn: Træk af folkeskolens historie i Nordslesvig 1864-1920, 1981, s. 119.

36. Se f.eks. LA Aab, Haderslev landråd, fag 139 nr. 28, regeringen i Slesvig til kirkevisitatoriet i Tørninglen 3. marts 1876.

37. Jf. Axel Henningsen: Beiträge zur Geschichte der Erwachsenenbildung in Schleswig-Holstein, Neumunster 1962, s. 38.

38. LA Aab, Aab landråd X B 4. - Haderslev kredsskoleinspektion I 335.

39. F.eks. pastor Kier i Øster Løgum 1881: LA Aab, Aab landråd X B 4 I.

40. LA Aab, Aab landråd X B 4 I, 6. nov. 1882.

41. LA Aab, Tønder landråd X Spec. 6 (pk. 630).

42. LA Aab, Tønder landråd X Spec. 6-8 (pk. 631).

43. LA Aab, Aab landråd X B 4 I.

44. G. Japsen: Den fejlslagne germanisering, 1983, s. 58, 78 og 101.

45. Hans Peter Johannsen: Sieben schleswigsche Jahrzehnte, Schleswig 1978, s. 45-47. - Sönnichsen, 1991, s. $21 \mathrm{f}$.

46. LA Aab, Aab landråd X B 4, grundsætninger for statsstøttede folkebiblioteker 1877.

47. Eksempel fra Hostrup sogn ved Tønder 1902. LA Aab, Tønder landråd X Spec. 8.

48. LA Aab, Aab landråd X B $4 \mathrm{I}$.

49. LA Aab, Aab landråd X B 4 II.

50. LASH, Abt. 301 nr. 2277. Abt. 309 nr. 12611.

51. LASH, Abt. 309 nr. 12611, Krage til regeringen i Slesvig 2. aug. 1897.

52. Anders Feilberg Jørgensen, 1980, s. 60; jf. SJy Årb 1905, s. 287.

53. LASH, Abt. 309 nr. 12611. Regeringspræsidenten 15. maj 1899.

54. LA Aab, Tønder landråd X Spec. 8. 